\title{
nAWYKI ŻYWIENIOWE ŁÓDZKICH GIMNAZJALISTÓW
}

\section{EATING HABITS OF LODZ JUNIOR HIGH SCHOOL STUDENTS}

\author{
Anna Cisińska \\ Zakład Nauczania Pielęgniarstwa z Pracowniami Praktycznymi \\ Pracownia Promocji Zdrowia \\ Uniwersytet Medyczny w Łodzi
}

DOI: https://doi.org/10.20883/pielpol.2017.58

\begin{abstract}
STRESZCZENIE
Wprowadzenie. Racjonalne i zbilansowane odżywianie w okresie dojrzewania warunkuje prawidłowy rozwój organizmu człowieka, a nierzadko determinuje kondycję zdrowotną na dalsze etapy życia. Na 3-letni okres nauki w gimnazjum przypada czas ważnych przemian psychofizycznych i swoiste apogeum dojrzewania.

Cel. Ocena nawyków żywieniowych łódzkiej młodzieży gimnazjalnej; sformułowanie wniosków na temat możliwych działań prewencyjnych, profilaktycznych i edukacyjnych, wspomagajacych moderowanie procesu kształcenia w szkołach oraz wspierających merytorycznie działania wychowawczo-opiekuńcze rodziców.

Materiałi metody. Badanie ankietowe (metoda wiodąca) oraz wywiad (jako metoda uzupełniająca) objęły uczniów losowo wytypowanych klas I-III z dwóch łódzkich gimnazjów - szkoły publicznej i szkoły niepublicznej - w sumie 218 gimnazjalistów.

Wyniki. Wśród wielu zaobserwowanych parametrów charakteryzujących nawyki żywieniowe najbardziej szokujący wydaje się fakt, że tylko 60,5 \% badanych zawsze przed wyjściem do szkoły spożywa śniadanie. Ponad $11 \%$ nigdy takiego posiłku nie zjada. Już w szkole 80\% uczniów spożywa przygotowane w domu posiłki - przede wszystkim w formie kanapek.

Wnioski. Zależność między prawidłowym odżywianiem a kondycją zdrowotną jest dość oczywista i na ogół niekwestionowana, praktyka w omawianym zakresie nie zawsze nadąża za teorią. Ważne są zalecenia lekarzy i dietetyków, treści kształcenia ujęte w ramach obowiązującej w szkołach podstawy programowej, kampanie promujące zdrowe odżywianie, a także popularyzacja badań naukowych z dziedziny nauk medycznych i pokrewnych dyscyplin.
\end{abstract}

SŁOWA KLUCZOWE: żywienie, uczeń, gimnazjum.

\section{Wprowadzenie}

Racjonalne i zbilansowane odżywianie w okresie dojrzewania warunkuje prawidłowy rozwój organizmu człowieka, a nierzadko determinuje kondycję zdrowotną na dalsze etapy życia. Na 3-letni okres nauki w gimnazjum przypada czas ważnych przemian psychofizycznych i swoiste apogeum dojrzewania [1]. Dynamika procesów biochemicznych w organizmie wymaga dostarczania wartościowych i niezbędnych do harmonijnego rozwoju

\begin{abstract}
Introduction. Rational and balanced nutrition in adolescence determines the proper development of the human body, and often determines the health condition of further stages of life. The three-year period of junior high school is the time of important changes, and the psychophysical specific maturing climax.

Aim. To rate habits of Lodz junior high school students; to draw conclusions on possible preventive measures, prevention and education, supporting the moderation of the learning process in schools, and supporting parents' substantive upbringing and caring actions.

Material and methods. The survey (a leading method) and an interview (a complementary method) included randomly selected students of grades I-III from two Lodz junior high schools - public schools and non-public schools - a total of 218 junior high school students.

Results. Among the many parameters observed, characterizing eating habits, the most shocking is the fact that only $60.5 \%$ of respondents always have breakfast before classes start. More than $11 \%$ do not have such a meal. At school $80 \%$ of pupils have meals prepared at home - primarily in the form of sandwiches.

Conclusions. Although the relationship between the proper nutrition and health condition is quite obvious and generally uncontested, the practice in this field does not always keep up with the theory. Recommendations of doctors and nutritionists, educational content included within the current school core curriculum, campaigns on healthy eating, as well as the popularization of scientific research in the field of medical science and related disciplines are of great importance.
\end{abstract}

KEYWORDS: nutrition, student, junior high school.

składników i mikroelementów, a niedobory niektórych z nich skutkują określonymi zaburzeniami. Jakość pożywienia, rozumiana jako wypadkowa wartości energetycznej posiłków oraz ich komplementarności pod względem biochemicznym, to najważniejszy, choć nie jedyny problem związany z odżywianiem. Istotne znaczenie ma częstotliwość posiłków oraz rozkład w czasie „dostaw kalorii" do organizmu adekwatnie do dobowego cyklu metabolizmu [2]. Eskalacja problemów zdro- 
wotnych, wynikających z nadwagi lub niedoboru witamin czy mikroelementów, jest nieuchronnym skutkiem zaniedbań w dziedzinie edukacji i kształtowania postaw prozdrowotnych.

\section{Cel}

Ocena nawyków żywieniowych łódzkiej młodzieży gimnazjalnej; sformułowanie wniosków na temat możliwych działań prewencyjnych, profilaktycznych i edukacyjnych, wspomagających moderowanie procesu kształcenia w szkołach oraz wspierających merytorycznie działania wychowawczo-opiekuńcze rodziców.

\section{Materiał i metody}

Badanie ankietowe (metoda wiodąca) oraz wywiad (jako metoda uzupełniająca) objęły uczniów losowo wytypowanych klas I-III z dwóch łódzkich gimnazjów szkoły publicznej i szkoły niepublicznej - w sumie 218 gimnazjalistów. Przedmiotem analizy były anonimowe kwestionariusze ankiet oraz kwestionariusze wywiadu. Na przeprowadzenie badania uzyskano zgodę Komisji Bioetycznej Uniwersytetu Medycznego w Łodzi (numer decyzji RNN/115/13/KB).

\section{Wyniki}

Przedstawiona praca stanowi fragment badań dotyczących postaw prozdrowotnych młodzieży gimnazjalnej na terenie Łodzi i województwa łódzkiego. Prezentuje ona wyniki dotyczące odżywiania uczniów w łódzkich szkołach gimnazjalnych. W pracy przedstawiono wybrane elementy analizy uzyskanych wyników.

Wśród wielu zaobserwowanych parametrów charakteryzujących nawyki żywieniowe najbardziej szokujący wydaje się fakt, że tylko 60,5\% badanych zawsze przed wyjściem do szkoły spożywa śniadanie. Ponad $11 \%$ nigdy takiego posiłku nie zjada (Rycina 1). Ten odsetek dzieci spożywających pierwsze śniadanie w domu może świadczyć o braku czasu, jak również o braku tradycji wspólnych posiłków wśród domowników. Dziecko, które uczęszcza do szkoły, powinno mieć wykształcony nawyk zjadania pierwszego śniadania przed wyjściem do szkoły.

Na pytanie „Jak często zjadasz śniadanie w szkole?” 42\% dzieci odparło, że zawsze spożywa drugie śniadanie w szkole. Natomiast prawie 30\% dzieci deklarowało, że je śniadanie często, 18,3\% - rzadko, a 8,2\%, że nigdy nie spożywa w szkole śniadań (Rycina 2).

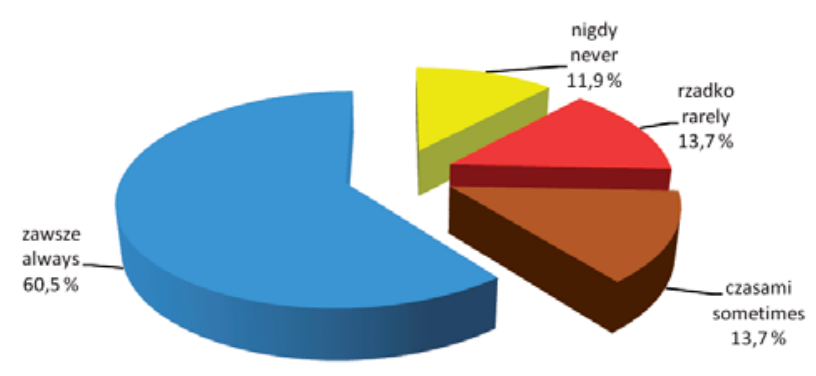

Rycina 1. Odsetek uczniów spożywających śniadanie przed wyjściem do szkoły

Figure 1. The percentage of students having breakfast before going to school

Źródło: badania własne

Source: author's own materials

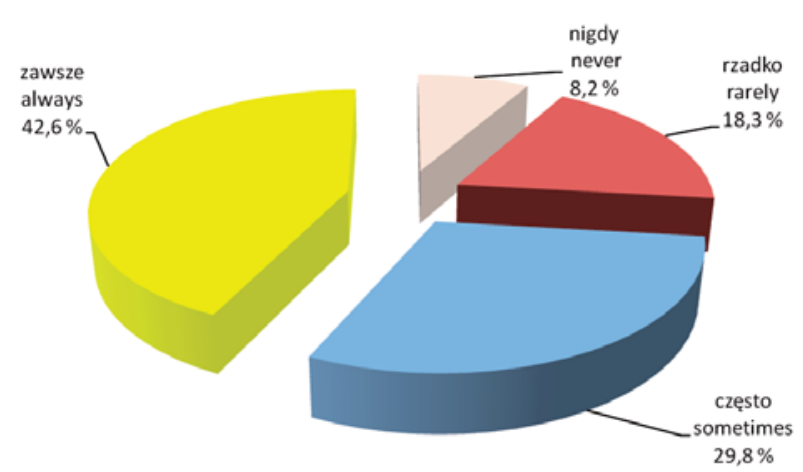

Rycina 2. Odsetek uczniów spożywających drugie śniadanie w szkole Figure 2. The percentage of students having lunch at school

Źródło: badania własne

Source: author's own materials

Uczniowie pytani o to, co najczęściej spożywają na drugie śniadanie, udzielili zróżnicowanych odpowiedzi. W szkole $80 \%$ uczniów spożywa przygotowane w domu posiłki - przede wszystkim w formie kanapek. Analiza składu tzw. drugich śniadań (choć dla wielu uczniów tak naprawdę pierwszych) wygląda niepokojąco. Choć 37\% uczniów spożywało owoce, to niemal tyle samo $(34,4 \%)$ wybrało cukry zawarte w pączkach, słodkich bułkach, batonikach i innych słodyczach. Na słone przekąski, przede wszystkim chipsy, wskazało 6,4\% uczniów, a tylko $18,8 \%$ badanych wymieniło nabiał jako składnik spożywanego w szkole posiłku.

Ważny element codziennej diety wśród dzieci i młodzieży powinny stanowić zdrowe produkty. Badanych uczniów zapytano o częstotliwość spożywania produktów korzystnych dla zdrowia: owoców, warzyw, mleka, ryb. Z przeprowadzonej analizy wynika, że tylko $27 \%$ badanych gimnazjalistów pije codziennie mleko, zaś $8,2 \%$ uczniów nigdy nie spożywa tego produktu. W badanej populacji owoce i warzywa są konsumowane codziennie przez ponad 65\% uczniów. Kilka razy w tygodniu warzywa i owoce spożywa ponad $70 \%$ ba- 
danych, raz w tygodniu - około $33 \%$ badanych, a deklaruje niejedzenie warzyw i owoców $8,6 \%$ badanych (Rycina 3).

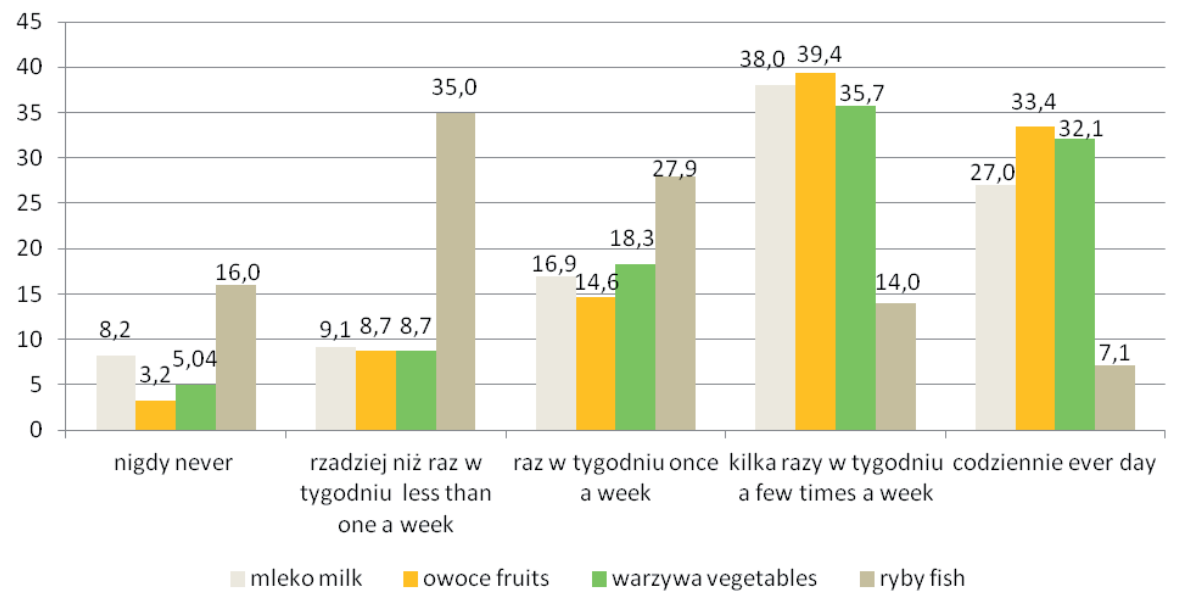

Rycina 3. Częstotliwość spożywania zdrowych produktów Figure 3. The frequency of healthy products consumption

Źródło: badania własne

Source: author's own materials

Z ankiety wynika również, że w pożywieniu gimnazjalistów występuje zbyt mała ilość kwasów tłuszczowych, których źródłem są ryby. Kilka razy w tygodniu ryby je 14\% uczniów, a 27,9\% - raz. Aż 35\% opisywanej grupy spożywa ryby rzadziej niż raz w tygodniu, natomiast $16 \%$ nie je ich w ogóle.

Ankietowanych zapytano też o częstotliwość spożywania produktów niezdrowych, takich jak: pączki, chipsy, ciastka. Nigdy nie je chipsów 40,3\% dzieci, zaś 18,8\% spożywa słone przekąski raz w tygodniu.
Jeśli chodzi o strukturę jakościową posiłków, za nadmierną masę ciała odpowiadają przede wszystkim cukry. Skłonność do nadużywania słodyczy - częściej obserwowana u chłopców - czasami przybiera postać wręcz uzależnienia. Uczniowie wskazywali na potrzebę codziennego sięgania po batoniki, czekoladki, lody czy ciastka. Przyczyny są różne: „nie potrafią się oprzeć”, dla poprawy nastroju, z uwagi na łatwość i szybkość dostarczenia organizmowi energii (Rycina 4).

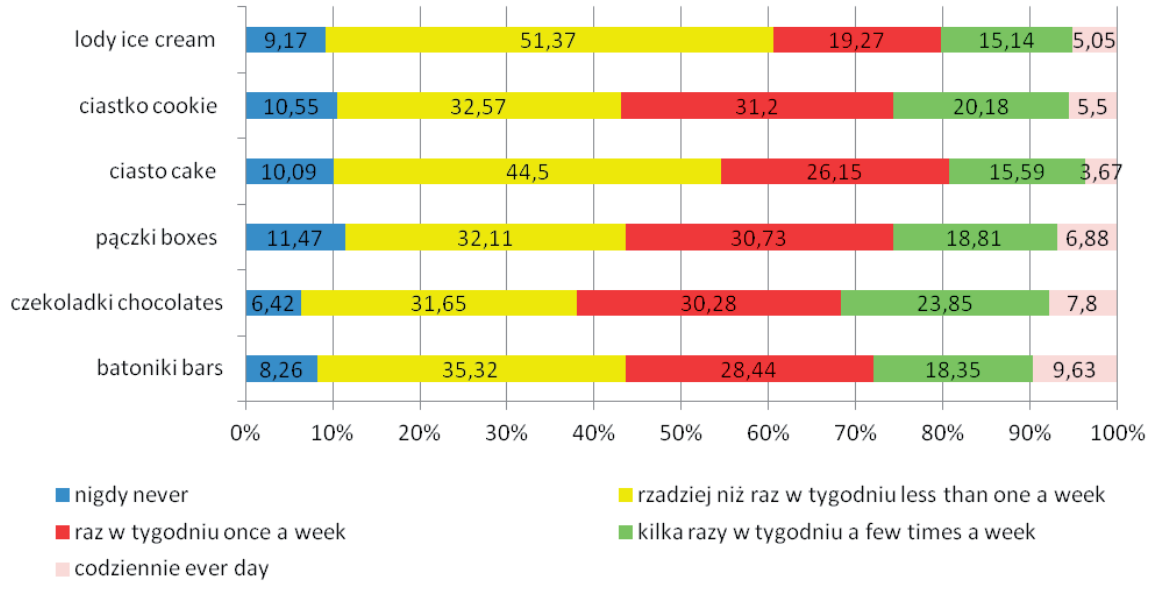

Rycina 4. Częstotliwość spożywania słodyczy przez uczniów Figure 4. The frequency of sweets consumption by students

Źródło: badania własne

Source: author's own materials 
Większość gimnazjalistów ocenia swój tryb życia jako zdrowy. Ponadto okazuje się, że dla dzieci głównym źródłem informacji na temat zdrowego trybu życia są: rodzice (ok. 20\%), Internet i telewizja (ok. 27\%), czasopisma $(9,1 \%)$, nauczyciele $(9,6 \%)$. Niepokojący jest fakt, że pracownicy ochrony zdrowia (pielęgniarki, lekarze) stanowią najmniejszy odsetek (8,5\%) wśród wymienianych przez uczniów źródeł informacji na temat zdrowego trybu życia. Powodem powyżej sytuacji może być ograniczony dostęp do pielęgniarki w szkołach.
Na podstawie przeprowadzonych badań dokonano oceny częstości spożywania napojów energetyzujących. Co ciekawe, w grupie badanych gimnazjalistów $36,7 \%$ deklarowało, że nie spożywa napojów energetyzujących. Kilka razy w tygodniu spożywa napoje 6\% uczniów, raz w tygodniu - 17\%, rzadziej niż raz w tygodniu - 30,2\% ankietowanych. Natomiast 10\% uczniów przyznało, że spożywa napoje energetyzujące codziennie (Rycina 5).

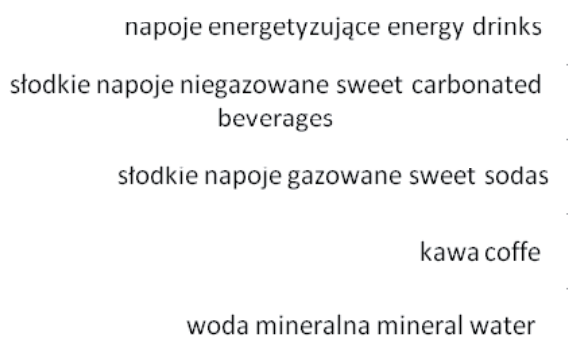

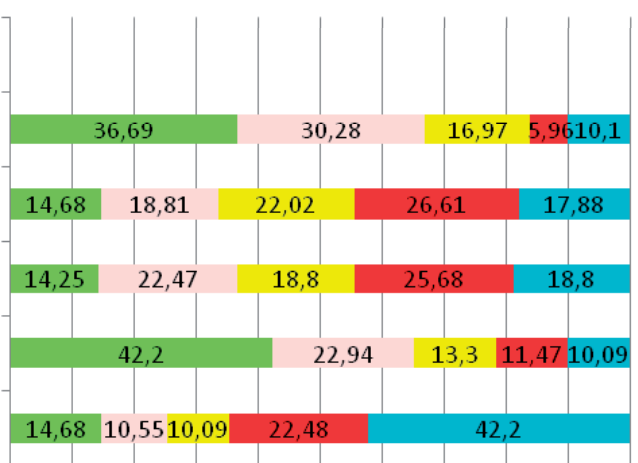

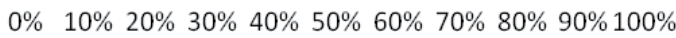

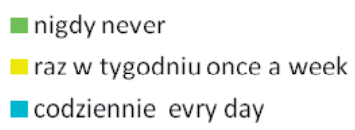

Rycina 5. Preferowane napoje spożywane przez uczniów Figure 5. Drinks consumed by students

Źródło: badania własne

Source: author's own materials

\section{Dyskusja}

Wśród wielu czynników mających wpływ na zdrowie człowieka należy wymienić nawyki żywieniowe [3]. Na przestrzeni kilku ostatnich lat w Polsce i na świecie zaobserwowano wśród dzieci i młodzieży zjawisko nieprawidłowości w odżywianiu objawiających się zarówno niedoborem, jak i nadmiernym spożyciem poszczególnych produktów. Niewłaściwe odżywianie przyczynia się do rozwoju wielu chorób, najpoważniejszymi schorzeniami w tym zakresie są nadwaga i otyłość [4].

Jednym ze znaczących czynników wpływających na prawidłowe odżywianie jest regularność spożywania posiłków. Na szczególną uwagę zasługuje regularne spożywanie śniadań. Powszechnie wiadomo, że śniadanie jest pierwszym i najważniejszym posiłkiem w ciągu dnia. Niestety mimo świadomości, jak ważny jest pierwszy posiłek, aż 15\% społeczeństwa nie spożywa go w ogóle [5]. Co gorsza, odsetek ten wzrasta szczególnie wśród dzieci i młodzieży, nawet co piąty uczeń nie je śniadania [5]. rzadziej niż raz w tygodniu less than one a week

kilka razy $w$ tygodniu a few times a week
Badania wskazują, że śniadanie wpływa korzystnie na koncentrację i pamięć, zmniejsza ryzyko wystąpienia chorób sercowo-naczyniowych i cukrzycy. Zaobserwowano, że częstotliwość występowania otyłości i zespołu insulinooporności jest niższa w grupie dzieci, które spożywają regularnie śniadanie [5]. Według badań prezentowanych $\mathrm{w}$ niniejszej pracy prawie $12 \%$ ankietowanych nigdy nie zjada śniadania przed wyjściem do szkoły. Wyniki badań Bucholc i wsp. przeprowadzone wśród 178 uczennic klas gimnazjalnych wskazały, że aż 30,2\% uczennic nie podejmowało tego typu działań [6]. Warto wspomnieć, że w 2002 roku przeprowadzono w Polsce badania dotyczące zachowań zdrowotnych dzieci szkolnych (Health Behaviour in School-aged Children), które wykazały, że tylko 47,5\% uczniów spożywa regularnie posiłki. Co ciekawe, zaobserwowano zależność, że im młodsze dzieci, tym większa regularność spożywania posiłków, a wraz z wiekiem ulega ona niekorzystnym zmianom [7]. 
Jeśli spojrzeć na popularność produktów spożywanych na drugie śniadanie przez dzieci, zarówno z badań własnych, jak i innych autorów wynika, że uczniowie najczęściej spożywają na drugie śniadanie kanapki przyniesione $z$ domu $[8,9]$.

Według opracowanych przez Instytut Żywności i Żywienia zasad zdrowego żywienia dzieci i młodzieży w diecie powinny znajdować się produkty mleczne, stanowiące główne źródło wapnia. Uczniowie zatem powinni wypijać 3-4 szklanki mleka dziennie albo część mleka zastępować przetworami mlecznymi (jogurty, kefiry, maślanka, sery). Prezentowane wyniki badań własnych wskazują, że tylko $27 \%$ uczniów pije mleko codziennie. Według obserwacji innych autorów w populacji dzieci w wieku 14-17 lat codzienne picie mleka deklarowała jedynie mniej więcej jedna piąta młodzieży, a połowa dzieci włączała do swojej diety mleko i napoje mleczne tylko raz w tygodniu lub rzadziej [10].

Wśród produktów spożywanych przez uczniów w badaniu Wojtyły-Buciory i wsp. przeprowadzonym na grupie 1100 uczniów szkół podstawowych zaobserwowano również zbyt niski odsetek uczniów konsumujących przetwory mleczne [9].

Młodzież gimnazjalna najczęściej podjada produkty żywnościowe o wysokiej kaloryczności, takie jak batoniki, czekoladki, pączki, ciastka. Analiza badań ankietowych wykazała, że jedzenie słodkich produktów jest częstym zjawiskiem wśród młodzieży gimnazjalnej, z której $30 \%$ je słodycze codziennie. Porównując te dane z wynikami innych autorów, można zauważyć, że słodycze (tzw. puste kalorie) są nierzadkim produktem w jadłospisie opisywanej grupy wiekowej.

Badania przeprowadzone wśród uczniów szkół z terenu trzech województw: mazowieckiego, łódzkiego i podlaskiego wykazały, że po napoje energetyzujące sięga odpowiednio 17\% uczniów szkół gimnazjalnych i 24\% ze szkół ponadgimnazjalnych [12].

Z licznych badań dotyczących spożywania napojów słodzonych przez dzieci wynika, że 50\% respondentów pije słodzone napoje kilka razy dziennie, 23\% - raz dziennie, a tylko 27\% - sporadycznie lub wcale [13]. W badaniach własnych zaobserwowano, że 37\% pije tego typu napoje codziennie, a ponad $50 \%$ - kilka razy w tygodniu. Raport WHO potwierdza, że wysokie spożycie słodzonych napojów stanowi czynnik sprzyjający wystąpieniu otyłości [14].

Z badań własnych wynika, że ponad 50\% uczniów spożywało napoje energetyzujące. W literaturze przedmiotu opisywane są negatywne dla organizmu dziecka skutki picia napojów energetyzujących. Amerykańska Akademia Pediatryczna w swoich badaniach opisuje, że u dzieci spożywających te napoje występują zaburzenia układu sercowo-naczyniowego, pokarmowego, otyłość, a także cukrzyca [14]. Z amerykańskich badań O’Dea wynika, że 42,3\% dzieci i młodzieży w wieku 11-18 lat piło napoje energetyzujące [12].

Kolejnym aspektem złego odżywiania jest stosowanie wśród gimnazjalistów różnego rodzaju diet. Badania prowadzone w dwóch ośrodkach (brytyjskim i amerykańskim) potwierdziły, że stosowanie diet przez młodzież jest czynnikiem predysponującym do występowania otyłości. Vinter i Cole zaobserwowali, że nastolatki, które stosowały diety odchudzające, były bardziej narażone na wystąpienie otyłości w późniejszym wieku niż osoby, które jej nie stosowały [15].

\section{Wnioski}

1. Nawyki żywieniowe nie uwzględniają w pełni zasad prawidłowego odżywiania. Dotyczy to przede wszystkim jakości posiłków, a w dalszej kolejności - ich ilości w skali doby, wartości energetycznej oraz częstotliwości.

2. Odpowiedzialność za postulowane oddziaływanie wychowawcze w celu eliminacji problemów spoczywa na wszystkich podmiotach uczestniczących w procesie dydaktyczno-wychowawczym - od rodziny po szkołę.

3. Ważna jest edukacja nieustannie implementująca młodym ludziom zasady prawidłowego odżywiania, zwłaszcza zbilansowanego komponowania posiłków oraz swoistej „kultury jedzenia", popularnej chociażby w kręgu społeczeństw śródziemnomorskich.

4. Ważne jest również edukowanie w zakresie krytycznej oceny składu produktów spożywczych oraz wzmacnianie świadomości związku przyczynowo-skutkowego między odżywianiem a stanem zdrowia, samopoczuciem i kondycją fizyczną.

5. Zasygnalizowany obszar działania to również pole do aktywności personelu medycznego, a przede wszystkim pielęgniarek szkolnych.

\section{Piśmiennictwo}

1. Kunachowicz H, Czarnowska-Misztal E, Turlejska H. Zasady żywienia człowieka. Warszawa: WSiP; 2013. 132-146.

2. Czerwińska D, Gulińska E. Podstawy żywienia człowieka. Warszawa: WSiP; 2005. 121-129.

3. Kłos J, Gromadecka-Sutkiewicz M. Styl życia młodzieży w ujęciu strukturalnym. Probl Hig Epidemiol. 2011; 92(1): 120-126.

4. Kolmaga A, Zimna-Walendzik E et al. Ocena stanu odżywienia 16-letniej młodzieży z łódzkich szkół ponadpodstawowych. Probl Hig Epidemiol. 2014; 95(1): 96.

5. Wądołowska L, Gajewska D et al. Śniadanie i jego znaczenie dla naszego zdrowia. Warszawa: belVita; 2013. 18-21.

6. Zbrońska I. Ocena sposobu żywienia uczniów szkoły podstawowej w Jędrzejowie pod kątem jego prawidłowości. Probl Hig Epidemiol. 2014; 95(4): 985-990.

7. Woynarowska B. Zachowania żywieniowe u młodzieży w wieku 11-15 lat w Polsce i ich niektóre skutki zdrowotne i społeczne. Stand Med Pedriatr. 2014; 1: 87-94. 
8. Chęcińska Z et al. Ocena sposobu żywienia młodzieży wielkomiejskiej i obszarów wiejskich. Probl Hig Epidemiol. 2013; 94(4):780-785.

9. Wojtyła-Buciora P et al. Sposób żywienia uczniów szkół podstawowych w powiecie kaliskim - w opinii dzieci i ich rodziców. Probl Hig Epidemiol. 2015; 96(1): 245-253.

10. Lange $E$ et al. Skład ciała i wybrane nawyki żywieniowe dzieci w wieku 14-17 lat. Bromat Chem Toksykol. 2011; 3: 389-397.

11. Ponczek D, Olszowy I. Styl życia młodzieży i jego wpływ na zdrowie. Probl Hig Epidemiol. 2012; 93(2): 264.

12. Błaszczyk E, Piórecka $B$ et al. Konsumpcja napojów energetyzujących i zachowania z nią związane wśród młodzieży wiejskiej. Probl Hig Epidemiol. 2013; 94(4): 815-819.

13. Królewska-Gawrzyńska J, Proc $P$ et al. Nawyki żywieniowe łódzkiej młodzieży licealnej w świetle badań ankietowych. Dent Med Probl. 2014; 51: 86-92.

14. Sosnowska-Bielicz E, Wrótniak J. Nawyki żywieniowe a otyłość dzieci w wieku przedszkolnym i szkolnym. Lubelski Rocznik Pedagogiczny. 2013; 32: 147-165.

15. Raport IASO/IOTF, www.iaso.org (data dostępu: 10.08.2016).
Artykuł przyjęty do redakcji: 15.09.2016

Artykuł przyjęty do publikacji: 16.02.2017

Źródło finansowania: Praca nie jest finansowana z żadnego źródła. Konflikt interesów: Autor deklaruje brak konfliktu interesów.

\section{Adres do korespondencji:}

Anna Ciesińska

ul. Stefana Jaracza 63

90-136 Łódź

tel. kom.: 661790637

e-mail: anna.ciesinska@umed.lodz.pl

Zakład Nauczania Pielęgniarstwa z Pracowniami Praktycznymi Uniwersytet Medyczny w Łodzi 